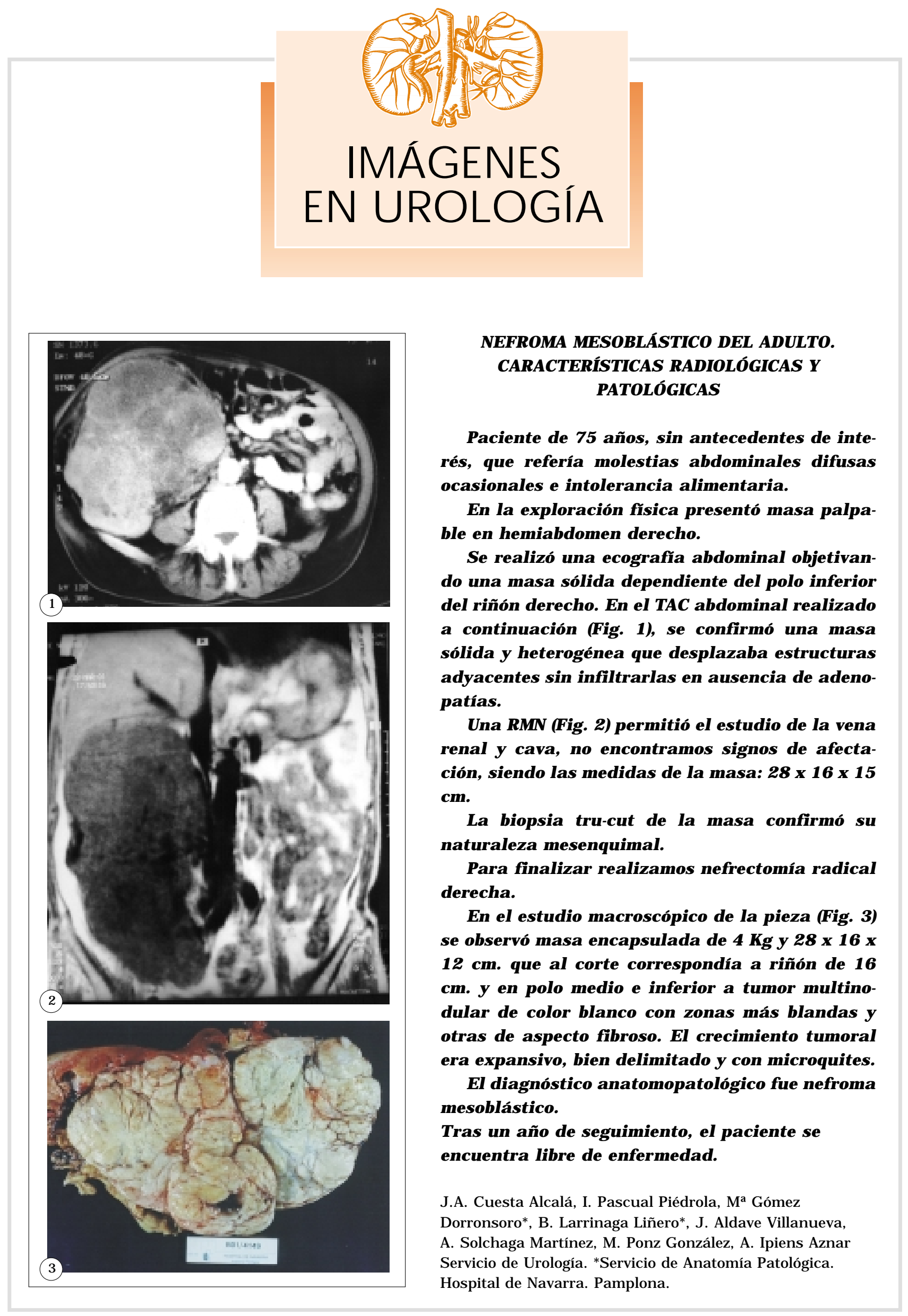




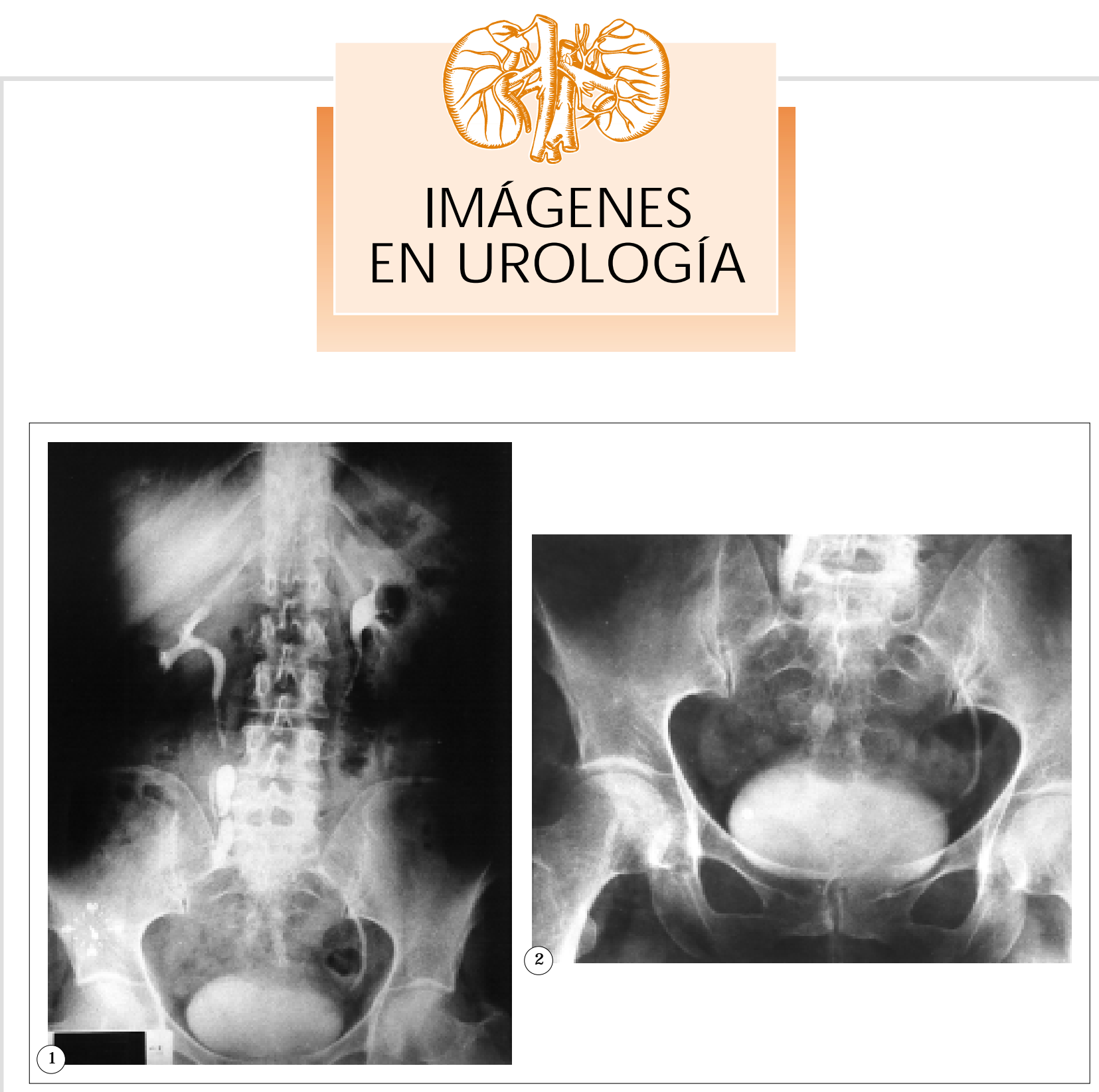

\section{DUPLICACIÓN CIEGA URETERAL ASOCIADA A CARCINOMA TRANSICIONAL DE VEJIGA}

Paciente que consulta por hematuria transitoria. Entre las pruebas complementarias se realiza urografia intravenosa objetivándose duplicación ciega de uréter derecho a nivel de tercio medio, junto a defecto de repleción intravesical. Mediante cistoscopia se confirma neoformación papilar lateral al orificio ureteral derecho, que se reseca siendo el resultado histológico informado como carcinoma transicional Ta GI . (Figs. 1 y 2).

La duplicación ciega ureteral es un hallazgo poco frecuente, más habitual en el lado derecho y en mujeres. Parece que el brote ureteral afectado aborta y no contacta con el metanefros. Se describe asociado a infecciones, cálculos, produciendo ocasionalmente sintomas como dolor abdominal crónico.

En nuestro caso es un hallazgo en un estudio por hematuria en relación con un carcinoma transicional de vejiga.

J. García Rodríguez, A. Jalón Monzón, O. Rodríguez Faba, J.M. Fernández Gómez, J.J. Rodríguez Martínez, J. Regadera Sejas

Servicio de Urología. Hospital Central de Asturias. Oviedo. 